\title{
Wildlife on Réunion
}

\author{
François Moutou
}

Réunion is probably the least well known of the islands of the Mascarene archipelago. The author, a veterinarian who spent two years working there, gives an account of its now much diminished wildlife and some of the problems facing the species that remain.

Although the three islands of the Mascarene archipelago have a large part of their history in common, each is strongly individual. Today, in terms of their natural history, Réunion seems to be less well known than Mauritius or even Rodriguez. In early 1979, before I left France for a two-year stay on Réunion, it was almost impossible to discover anything about its wildlife in Paris.

Réunion is a young oceanic and volcanic island of
$2512 \mathrm{sq} \mathrm{km}$. One first notices the astonishing topography; flat areas are nearly non-existent and the plaines is a term usually describing areas that are 'highlands with a lesser slope'. Secondly, one notices the extensive sugar cane plantations. Nearly all the lowland forests have disappeared except some small patches at the foot of the stillactive volcano, Piton de la Fournaise. The combination of topography and forest clearance means that soil erosion is very marked, as shown by every tropical downpour.

Evergreen rain forest still covers a large belt around the two Pitons (Piton des Neiges, $3069 \mathrm{~m}$ and Piton de la Fournaise, $2631 \mathrm{~m}$ ) 'which are both naked due to altitude and volcaric activity (Cadet, 1980, 1981). But development of the island proceeds and deforestation continues. Nearly all reafforestation uses Japanese red cedar

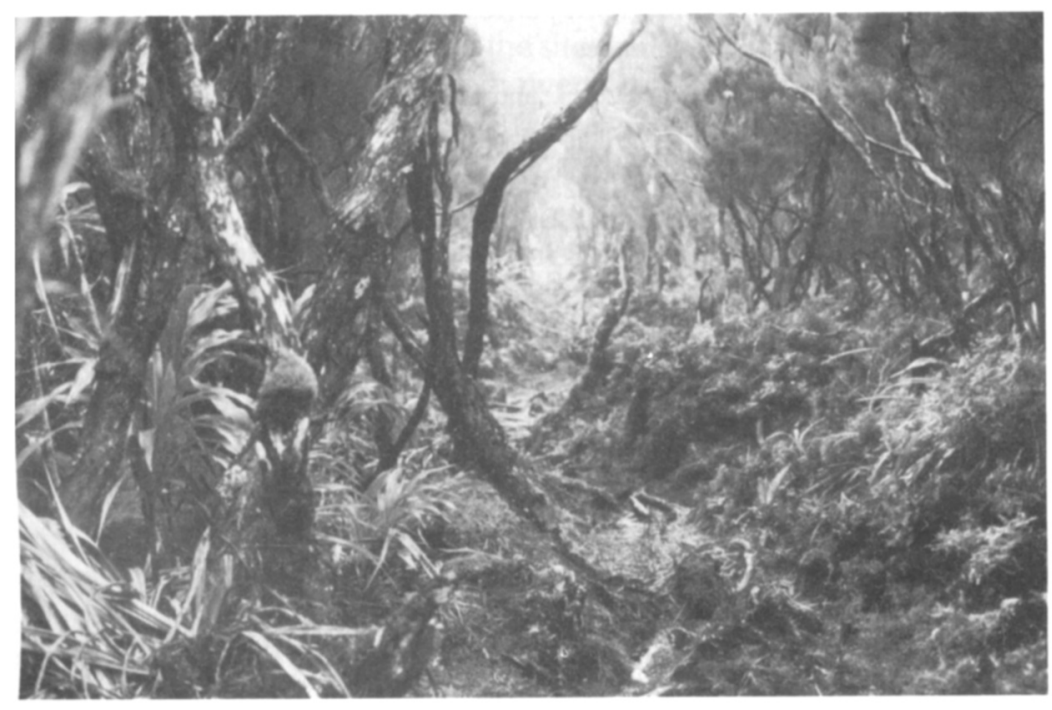

160
Forest between Piton des Neiges and Belouve, at approximately $2000 \mathrm{~m}$, showing Philippia sp. (François Moutou).

Oryx Vol 18 No 3 

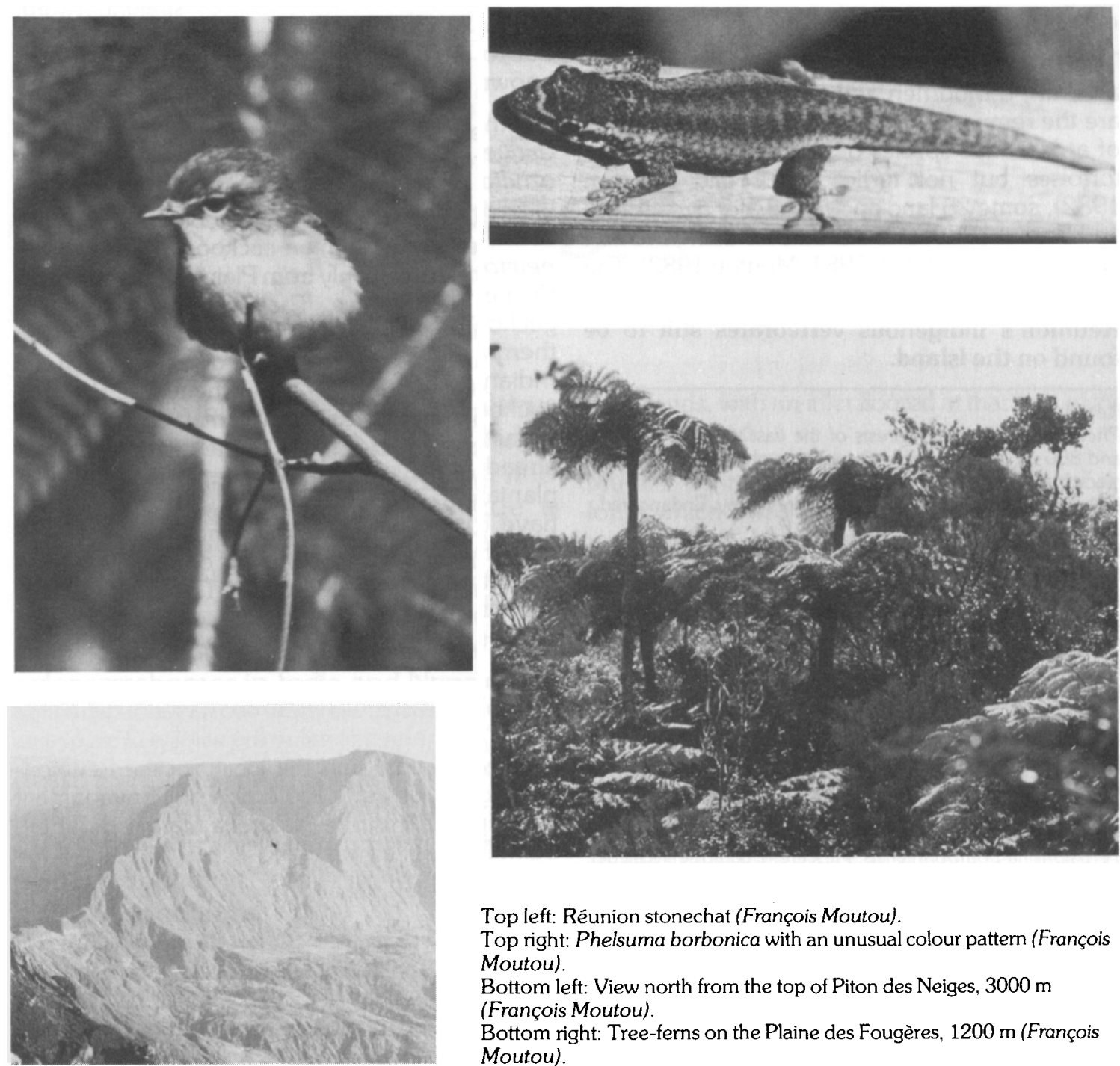

Top left: Réunion stonechat (François Moutou).

Top right: Phelsuma borbonica with an unusual colour pattern (François Moutou).

Bottom left: View north from the top of Piton des Neiges, $3000 \mathrm{~m}$

(François Moutou).

Bottom right: Tree-ferns on the Plaine des Fougères, $1200 \mathrm{~m}$ (François Moutou).

Cryptomeria japonica and it is difficult to predict the outcome of this. The sad thing is that all is conducted by the Office National des Forêts (ONF), which does not seem fully to understand the tropical rain forest of Réunion.

With such disruption of the flora, the fauna must have passed through dramatic changes since the first human settlement, a little more than 300 years ago. The list of known exterminations is impressive. As vertebrates have been better described than invertebrates, we shall mainly refer to the former (Moutou, 1983).

Wildlife on Réunion
Compared with Mauritius and Rodriguez, the extinct fauna of Réunion is still poorly known: no remains of the Réunion solitaire Raphus solitarius or of almost any other native birds; a single skull of the endemic land tortoise Cylindraspis borbonica. Very few people have ever dug for fossils. The fact is that very few suitable places exist because of the sharp relief, but there are some, as shown in 1980 when R. Bour from Paris Museum searched for tortoise remains. A few were found (Bour, 1981) associated with bird bones, but much more could be done. On the 
other hand, many people have searched the entire island for hypothetical pirate treasure!

Today two geckos, nine land birds, five seabirds, a heron, a moorhen and two insectivorous bats are the remnant of a fauna which once consisted of at least five species of reptiles, including land tortoises but not turtles (Bour and Moutou, 1982), some 25 land and freshwater birds (Barré and Barau, 1982) and five bats including two fruit bats (Cheke and Dahl, 1981; Moutou 1982). The

Réunion's indigenous vertebrates still to be found on the island.

\section{Reptiles}

Phelsuma borbonica. Forests of the east part between 400 and $800 \mathrm{~m}$. Nowhere abundant, although not uncommon in places

$P$. ornata inexpectata. Confined to Manapany. Endangered

\section{Birds}

Circus aeruginosus maillardi, marsh harrier. May be seen from sea-level to $2000 \mathrm{~m}$

Collocalia francica, grey-rumped swiftlet. seen from

Common sea-level

Phedina borbonica, Mascarene martin. Quite to $2500 \mathrm{~m}$

common

Coracina newtoni, Réunion cuckoo-shrike. Restricted to a small area. Endangered

Hypsipetes borbonicus, Rêunion bulbul. Found only in the forests. Suffers from hunting and poaching

Saxicola torquata tectes, Rêunion stonechat. May reach 3000 $\mathrm{m}$ (Piton des Neiges). Mainly in the forests

Terpsiphone bourbonniensis, Mascarene paradise flycatcher. Confined to the forests

Zosterops borbonica, Mascarene grey white-eye. The only one to be seen even in St Denis's gardens

Z. olivacea, Mascarene olive white-eye. Confined to the forests

Gallinula chloropus pyrrhorhoa, moorhen. Small populations in some estuaries

Ardeola idae, Madagascar heron. Rediscovered in 1979. Two nesting populations

Phaethon lepturus lepturus, white-tailed tropicbird. Quite common

Anous stolidus, brown noddy. A few nesting colonies around Petite lle (SW coast)

Puffinus lherminieri, Audubon's shearwater. Quite common Pterodroma baraui, Réunion petrel. Discovered in 1963 and quite common. Some nesting places above $2500 \mathrm{~m}$

$P$. aterrima, Mascarene black petrel. Found twice in 100 years. Nesting places unknown

\section{Bats}

Tadarida acetabulosus, Natal wrinkle-lipped bat. Common, some large roosting colonies

Taphozous mauritianus, Mauritian tomb bat. Common, seems to carry out annual migrations reasons for extinction are straightforward: destruction of natural forests, hunting and introduction of rats, dogs, cats, pigs, goats . . . a well known story.

Of the surviving species, the two most endangered are the Manapany gecko Phelsuma ornata inexpectata, known only from the single locality of Manapany-les-bains, on the south-west coast, and the Reunion cuckoo-shrike Coracina newtoni, known only from Plaine des Chicots and Plaine d'Affouches. The main danger for the gecko is collectors, who fly from Europe to catch them and related species on other islands of the Indian Ocean in order to sell them. The Réunion cuckoo-shrike faces much human disturbance in its last stronghold; some of the native forest has already been converted to Japanese red cedar plantations, Javan deer Cervus timorensis russa have been introduced for hunting in the Plaine des Chicots, and poaching still occurs. Deer are a real hazard in such a place. The ONF warden reports that some plants are becoming scarce due to the selective browsing of deer.

Like anywhere else in the world, it will only be possible to achieve nature conservation when the island's inhabitants value the wildlife. This begins with education, and the local Société Réunionnaise d'Etude et de Protection de l'Environment (Muséum d'Histoire Naturelle, Jardin de l'Etat, Saint Denis) has this aim.

\section{References}

Barré, N. and Barau, A. 1982. Les Oiseaux de la Réunion. Saint Denis de-la-Réunion.

Bour, R. 1981. Histoire de la tortue terrestre de Bourbon. Bull. Acad. Île Réunion, 25, 98-147.

Bour, R. and Moutou, F. 1982. Reptiles et Amphibiens de l'île de la Réunion. Info-Nature lle Réunion, 19, 121-156.

Cadet, T. 1980. La végétation de l'ile de la Réunion. Etude phyto-écologique et phytosociologique. Cazal. Saint Denis de la Réunion pp. 1-312.

Cadet, T. 1981. Fleurs et Plantes de la Réunion et de l'ile Maurice. pp. 1-131. Les éditions du Pacifique. Papeete. Tahiti.

Cheke, A.S. and Dahl, J.F. 1981. The status of bats on western Indian Ocean islands, with special reference to Pteropus. Mammalia, 45(2), 205-238.

Moutou, F. 1982. Note sur les chiroptères de l'íle de la Réunion (Océan Indien). Mammalia, 46(1), 35-51.

Moutou, F. 1983. Les peuplements des vertébrés terrestres des îles Mascareignes. Revue d'Ecologie La Terre et la Vie 37(1), 21-35.

François Moutou, 22 rue Mouffetard, 75005 Paris, France. 